\title{
Religiosity, masculinity, and marital and life satisfaction among Balinese Hindu men
}

\author{
Wade, Jay C. $\triangle$ \\ Fordham University, USA (jcarlylewade@gmail.com)
}

Suryani, Luh Ketut

Udayana University and the Suryani Institute of Mental Health, Indonesia (suryani@suryani-institute.com)

Lesmana, Cokorda Bagus Jaya

Udayana University and the Suryani Institute of Mental Health, Indonesia (cokorda@suryani-institute.com)

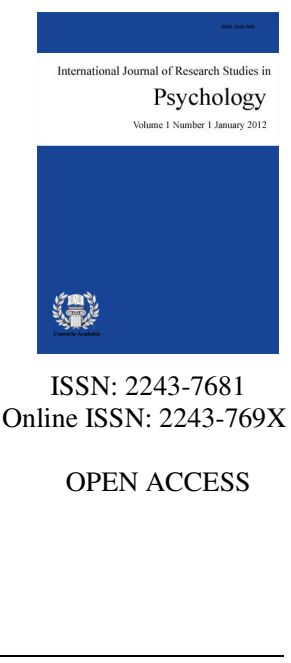

\section{Abstract}

This exploratory study describes Balinese Hindu men's definitions of masculinity or manhood. The research study involved direct and participant observation, interviewing key informants, group interviews with Balinese men, and survey research. In this sequential mixed-methods research design, the construct of masculinity was operationalized and relationships between religiosity, masculinity, and marital and life satisfaction were explored. Five areas were identified that describe Balinese masculinity: head of family, protector and provider, caring for others, strength of character, and characteristics of the self. The survey research showed that head of the family as an important masculinity experience was associated with satisfaction with one's marriage. Multiple regression analysis indicated that caring for others was the only significant predictor of life satisfaction. Religiosity related positively to the importance of the masculinity experiences and life satisfaction, and accounted for the positive relationship between masculinity and life satisfaction. The findings are discussed within the context of Balinese religious culture.

Keywords: Balinese men; masculinity; marriage; culture; religion; spirituality 


\section{Religiosity, masculinity, and marital and life satisfaction among Balinese Hindu men}

\section{Introduction}

Bali has a population of 4.22 million people and is home to most of Indonesia's Hindu minority; about $92 \%$ of Bali's population adhere to Balinese Hinduism (World Hindu Parisad, n. d.), whereas 87.2\% of Indonesia's population is Muslim (Pew Research Center, 2015). Over the last three decades tourism has become the largest single industry in terms of income (Radzmi, 2014). However, as a consequence of Western tourist culture, global popular culture and media, and urbanization, Balinese gender relations are currently in flux (Parker, 2003). Ideals of masculinity and femininity have been shifting as well. Masculine ideals of physical strength and endurance, community participation, leadership, and responsibility are in decline; men are increasingly identified with, and measured by, the economic well-being of their nuclear family (Parker, 2003). Similarly, Suryani (2004) acknowledged how the aforementioned outside influences on Bali-promoting values of consumerism, individualism, and competition that are at odds with the Balinese values of balance, community, and harmony-have engendered a plethora of social problems on the island: prostitution, substance abuse, and HIV/AIDS. Lewis and Lewis (2009) contended that these forces and associated changes have resulted in deep psychological and cultural trauma that remains largely unacknowledged.

Additionally, since democratic reforms were introduced after the fall of autocratic president Suharto in 1998, commensurate emancipation in the role of women appears to have contributed to a sharp, inadvertent rise in divorce rates that is not limited to Bali, but has been observed across Indonesia (IANS, 2009). The majority of divorces were caused by general family disharmony and most of the divorces have been initiated by women (IANS, 2009). The political transition that occurred with the end of Suharto's rule had the effect of Indonesian women becoming more assertive in the exercise of their rights (Cammack, Bedner, \& van Huis, 2015). Adamson (2007) argued that towards the end of Suharto's rule until the present day there has been the concern of women not needing men, which has been in concert with changes occurring in Indonesia with regard to increasingly becoming part of a global economic system and new educational and work opportunities for women. Thus, cultural anxiety about the breakdown of the family became associated with increasing Western influences and changing gender roles.

Although the Indonesian Marriage Law (Law of the Republic of Indonesia Number 1 of the Year 1974 on Marriage) adopts the principle of equality between husband and wife in the family and in society, it specifies that the husband is the head of the family and the wife is the mother of the household; the husband has the responsibility to protect his wife and support her to the best of his abilities, and the wife has the responsibility of managing the household to the best of her abilities (Salim \& Azra, 2003). Additionally, national law may be different from ethnic-based laws and customs known as "adat." Balinese society is patriarchal, and before the Marriage Law of 1974, marriage was basically ruled using the adat law (Lukito, 2012); and adat rules predominate in civil problems, such as divorce, despite the national unified Marriage Law (Poerwandari, Sadli, \& Ihromi, 2005).

Traditionally in Bali, children are considered to belong to the husband's patrilineage; that is, the children belong to their father's family and as adults become part of his banjar (every area in Bali is run by a local banjar, or traditional village council). As such, in the case of divorce, women lose custody of their children (Parker, 2003). The patrilineal family system is a strong deterrent to divorce such that women may stay in unhappy marriages in order not to lose their children (Parker, 2003). In 2015, there were 594 reported cases of domestic violence and child abuse toward women and children in Bali (Kurniawan \& Chandra, 2016), a rate that is viewed as high and consistent with previous years as more women and girls are speaking up (Christensen, 2013; Winarti, 2013). 
These "recent social and political developments have ensured that the question of men in Indonesian gender studies has assumed a greater sense of urgency" (Clark, 2010, p. 28). Therefore, the aim of the present research was to gain knowledge of the gendered lives of Balinese men to better understand and address issues critical to the personal lives of Balinese men and women.

\subsection{Balinese culture and traditional gender roles}

In his seminal book, Island of Bali, Miguel Covarrubias (1937) provided a detailed description of Balinese culture and religion. Balinese Hinduism is a unique form of Hinduism practiced in Bali. Balinese see the world populated with good and bad spirits, gods and demons. The key to life is balance, of good and bad, negative and positive energies. Balinese believe in Tri Hita Karana, which means three causes of well-being or happiness: 1) harmonious relationships among people, 2) harmony with God, and 3) harmony with nature (Wayan, 2015). Maintaining balance (harmony) and doing good deeds brings peace, prosperity, and a happy life (Suryani, 2004). Balinese society is communal and there is a sense of community responsibility. All activities in the village are a communal effort, and a person belongs to their family as well as their village (Newell \& Stubbs, 1999).

When a couple marries the woman follows the man and lives in his home in his village. According to Suryani (2004), in traditional Balinese society women and men learn to fulfill complementary roles that are regarded as traditional responsibilities. The husband and wife cooperate to build their household, extended family, and community. A man attends to banjar duties and other activities that are defined as male. A woman attends to household and child rearing duties and caring for her husband. Additionally, she prepares the offerings to the gods. Men are the heads of families and represent their families in the banjar and village. Balinese women are never banned from taking on work roles outside of the home or even the highest positions in society. Oftentimes they also work outside of the home to produce income.

Parker (2003) provided a detailed description of familial and parental roles in Balinese culture. In particular, she noted that "although boy babies are generally more welcome than girl babies-for reasons of family- and kin-group maintenance, performance of death rituals, inheritance, and so on-there is no great difference in their treatment; babies of both sexes are treated 'as gods' and are much loved" (p. 307). Parenthood is a key social role. "A Balinese [sic] feels that his most important duty is to marry as soon as he comes of age and to raise a family to perpetuate his line" (Covarrubias, 1937, p. 102). Men have duties to their parents, ancestors, and children. The father is considered the head of the household, principal breadwinner, and moral authority in the family. Mothers are considered the emotional heart of the family, responsible for the health and happiness of the family.

\subsection{The current study}

The current study is an extension of Marshall Clark's cultural analysis of constructions of the masculine in contemporary Indonesian society. In his book, Maskulinitas: Culture, Gender and Politics in Indonesia, Clark (2010) argued for the relevance of increased attention to the subject of men and masculine identity in Indonesia in a post-authoritarian Indonesia. Thus, the purpose of this study was to discover how Balinese Hindu men define masculinity or manhood, and whether men's masculinity is related to their marital and life satisfaction. Additionally, given the significance of Balinese Hinduism, religiosity was examined as a correlate of masculinity, marital satisfaction, and life satisfaction. Specifically, this exploratory study sought answers to the following research questions:

1. How do Balinese men define masculinity/manhood?

2. What are the relationships between masculinity, marital satisfaction, and life satisfaction?

3. What is the relationship between religion/spirituality and masculinity?

4. What is the relationship between religion/spirituality and men's marital and life satisfaction?

We used a sequential mixed-methods strategy that involved collecting data in an iterative process, whereby the data collected in one phase contributed to the data collected in the next. The qualitative study involved 
Wade, J. C., Suryani, L. K., \& Lesmana, C. B. J.

conducting group interviews with Balinese Hindu men to collect substantive data on their experiences and perspectives on manhood. The quantitative study was descriptive research conducted with Balinese Hindu men that investigated masculinity and religiosity as correlates of marital and life satisfaction.

\section{Qualitative study}

\subsection{The researchers}

The first author was the principal investigator who is an African American male that received a Fulbright Senior Research Scholar Award to conduct research on marital and life satisfaction among Indonesian men. The research was approved by the university Institutional Review Board and the State Ministry of Research and Technology in Indonesia. He lived in Bali for six months in which the implementation of the research project had three phases. The initial phase involved three months of direct and participant observation and reading books on Balinese history and culture as an approach to understanding Balinese culture and gender roles. The second phase involved interviewing two key informants and conducting group interviews with Balinese men. The third phase involved conducting survey research. The two collaborators on the research project were a female Balinese psychiatrist and professor, and her son who is also a psychiatrist and professor. Both collaborators also have a doctorate in psychology. There were several meetings throughout the project in which the researchers discussed the implementation of the project and differences in Balinese and American or Western cultures.

\subsection{Research design}

Direct observation, participant observation, and key informant interviews were the initial approaches to understanding the culture of Bali; in particular, religion, history, societal norms, the effect of the tourist industry, traditional gender roles, changes in gender roles in the emancipation era, and how manhood is defined and experienced. The principal investigator observed and participated in cultural traditions and events (e.g., a wedding, holiday ceremonies, events in a park), and interacted with Balinese men (e.g., taxi drivers, tour guides, new acquaintanceships) that sometimes included informal interviews. The principal investigator selected two key informants based on the following criteria: 1) they have much knowledge about Balinese culture and are well connected within their communities; 2) they have special insight about the larger social, cultural, and/or political factors that might affect local conditions and behaviors; 3) they have different backgrounds that can offer varying perspectives. Consequently, the two key informants were the second author and a 70 year old Balinese Hindu man who had worked in the tourist industry. These semi-structured interviews were conducted in English and concerned questions related to Balinese culture, gender roles, and the effect of the tourism industry on Balinese people and society.

The researchers met on two occasions to discuss the setting, structure, and content for the group interviews. The purpose of the group interview is to systematically question several individuals simultaneously, in formal or informal settings (Fontana \& Frey, 1994). In group interviewing the emphasis is on questions and responses between the researcher and participants. Given the language differences between the principal investigator and group participants, the researchers agreed that a format that allowed for questions and answers would best suit the needs for collecting data. The researchers also agreed that it would be appropriate for the principal investigator to give the participants remuneration in the amount of 100,000 IDR (\$10 USD).

\subsection{Participants}

The collaborators recruited the participants for the group interviews by asking men they knew if they would like to be involved in a research project on Balinese men. The men were also told that they could invite other Balinese men to be a part of the project. Participants had to be at least 21 years old. An effort was made to recruit participants representing different developmental age groups and statuses (e.g., college men, working men, professional men, married men) to allow for diverse experiences and perspectives. Two group interview sessions 
Religiosity, masculinity, and marital and life satisfaction among Balinese Hindu men

were held that included a total of 12 participants. Participants' ages ranged from 26 to 61 years old as follows: $20 \mathrm{~s}(1), 30 \mathrm{~s}$ (4), 40s (2), 50s (4), 60s (1). Eleven of the 12 participants were married, and the length of the marriages ranged from two months to 33 years. However, 7 of the men were married 20+ years. Most of the men worked in the tourist industry.

\subsection{Data collection}

The group interviews were co-led by the three researchers and held in the home of the second author. The interviews were conducted in Indonesian and the third author performed the translations. First, the principal investigator introduced himself and told the group about his background and reasons for conducting the study. He asked for permission to audiotape the session and provided contact information. Next, the men completed a questionnaire. (Details on the questionnaire are provided in the description of the survey study.) After completing the questionnaire, the principal investigator began the interview using pre-set questions. Questions asked at the beginning of the group were developed to get the participants comfortable with the experience of disclosing to others. As such, each person was asked to tell their name, where they are from in Bali, and anything about their family. The next set of questions were designed to have the men talk about the kinds of things men do and what they have observed, rather than asking them to focus on themselves. In this way, the men were the principal investigator's observers, so to speak, and their descriptions would not be filtered by their self-concepts. As the men became more comfortable talking in the group the questions were designed to have them describe their own lives.

\subsection{Results}

The principal investigator analyzed the data from notes taken and the audiotape of the sessions. Responses for each question were first listed with that question. When responses were similar, the one response that best characterized the responses was selected. The list of responses were then interpreted to provide a summary of the responses. The researchers met to review the principal investigator's results and discuss their accuracy. Participant's responses to the interview questions are provided in Table 1 and a summary interpretation is provided below.

The participants described men who have had an influence on them-their male reference group or male role model-and thereby men who represent the good qualities of manhood. Such men gave them advice on how to be a man. Their responses were consistent with Balinese cultural values related to the importance of family, harmony, and community. Additionally, there were values that were particular to manhood that signified achievement and personal growth. However, when describing men they did not want to be like, participants were describing the qualities of manhood they reject. Such characteristics were contrary to Balinese cultural values, in particular those that signified undesirable relationships and activities; for example, selling drugs, gambling, greed, not getting along well with others, and cheating others. The negative activities were also viewed within the context of relationships, because activities like selling drugs and gambling were "not good because it could affect other people."

The cultural tenets of Balinese manhood were also evident in their descriptions of experiences that made them feel like a man. Manhood means taking on family and community responsibilities. Fulfilling these tenets makes one feel like a man because they are fulfilling the male gender roles of Balinese society. By doing so, there is continuity between the actual (masculine) self and ideal (masculine) self within a cultural context.

The participants described enjoyable and difficult experiences in their life related to being a man. These experiences illustrated the meaning of manhood and masculinity. Half of the enjoyable experiences involved activities with male friends and/or in one's youth. It is possible that one's most poignant experience in this regard would be a memory from one's youth, perhaps because it was the first time they felt like a man thereby giving the experience more valence. Another possibility is the male reference group has particular importance in confirming 
Wade, J. C., Suryani, L. K., \& Lesmana, C. B. J.

one's male identity (Wade, 1998). Being a man or masculine means doing things with other males that males do. Comparatively, what is difficult in being a man concerns not having enough money and having to be emotionally strong. Having enough money was specific to dating, and not having enough affects one's sense of manhood.

Being emotionally strong is what differentiates men from women; because being a man means not expressing feelings such as sadness. In general, their responses indicate that difficulties associated with being a man are having to live up to certain expectations as a man in comparison to what is afforded women.

\section{Table 1}

Summary of Responses to Group Interview Questions

Tell me about the man who has been the greatest influence on you.

$>\quad$ Family as very important, do anything for family

$>$ Doing for others without regard for payment

$>\quad$ Not acting like you are better than others

$>$ Gave advice about the mind and body

$>$ Strong and wise

$>$ Attention to children

$>$ Value education

$>\quad$ Work hard

$>$ Heroism

$>\quad$ Doing a job well

$>\quad$ Making others happy

Describe men you have met or you know that you would not want to be like.

$>\quad$ Involvement in illegal activities: easy money, selling drugs, selling bad food, gambling

$>$ Talking about others negatively, gossip

$>$ Devalues education

$>$ Greed

$>\quad$ No friends, or does not get along well with others, negative interpersonal relationships

$>\quad$ Cheating others

What situations or experiences in your life have contributed to you feeling like a man?

$>\quad$ Getting advice from father about being a man or what are men's roles

$>$ Community activities that are a man's job

$>$ Community responsibilities (after marriage)

$>$ Having a son gives value as a man

$>$ Responsibility to children

What particularly enjoyable experiences in your life have been related to being a man?

$>\quad$ Playing with friends in high school

$>\quad$ When playing with friends being selected first to be on a team, gave a sense of pride

$>\quad$ At young age being rewarded for pushing a boat

$>$ Climbing a mountain giving a hand to a woman

$>$ Give understanding to family to create harmony

$>\quad$ Playing sport with friends and winning

What particularly difficult experiences in your life have been related to being a man?

$>\quad$ Having to work as a child

$>\quad$ Not being able to comfort his own feelings, not being allowed to express feelings of sadness

$>\quad$ Dating a woman when having no money

$>$ Having comparatively nothing to what the woman he loved had

\section{Survey Research}

\subsection{Participants}

Participants were 88 Balinese Hindu men with a mean age of 33.91 years $(S D=10.13)$. The 88 participants included 76 men recruited at a local park who completed all measures (except the measure for marital satisfaction if not married) and the 12 men from the group interview who completed the questionnaire except for the masculinity measure because it was developed after the group interview. Seventy-one (80.7\%) were married, and $69.5 \%$ were either an owner of a business, self-employed driver/tour guide, or manager of villas. Years 
Religiosity, masculinity, and marital and life satisfaction among Balinese Hindu men

married ranged from 6 months to 33 years, with an average of 9.64 years $(S D=8.60)$.

\subsection{Measures}

All measures were translated into Indonesian using forward and back translation that involved three steps. First, forward translation was done by a web-based translation service. Next, a bilingual Balinese research assistant reviewed the Indonesian version for accuracy and performed back translation. The research assistant identified several words and concepts that were not comprehensible. For example, the web-based serviced translated "masculinity" into "maskulinitas," but this is not a term that is understood or commonly used in the Indonesian language. Therefore, the researcher and assistant had to determine what words within the Indonesian language could best communicate this concept so it would be understood by the participants. Lastly, a second bilingual Balinese research assistant reviewed the measure for accuracy of the English to Indonesian translation comparing the original and back-translated versions for consistency between their meanings. Given many Balinese have some knowledge of the English language, each item was presented in Indonesian with the English version of the item directly underneath. In this way participants could choose to check the English translation of the item for their own understanding of what is being asked in Indonesian.

Masculinity Experiences Scale (MES) - The MES was developed to assess the importance of Balinese masculinity experiences. The construction of the MES was based on the Inventory of Subjective Masculinity Experiences (ISME) developed by Wong et al. (2011). A distinctive feature of the ISME is that it is a quantitative measure that is based on qualitative data. Dimensions of masculinity experiences are identified through a qualitative approach based on the number of times participants provide descriptions that fit the dimensions (Wong et al., 2011). An analogous approach was used to develop the MES. The participants in the group interview completed a sentence completion task in which they were given the following instructions: "Please describe your personal experience of what it means to be a man by completing the following sentence, 'As a man ...' 10 times. Just give 10 different responses. Respond as if you were giving the answers to yourself, not to somebody else. There are no right or wrong responses. Simply write down the first thoughts that come to your mind." Underneath the instructions, "As a man___ "was provided ten times. These responses were used as qualitative data to inform the development of the MES. First, the responses that were written in Indonesian were translated to English by the research assistant. Next, responses that were basically saying the same thing were evaluated and the one response that best represented the idea was selected. The remaining responses were then grouped together based on similarity of content. These responses were then analyzed for thematic representation.

There were 76 responses to "As a man" that initially fell into eight thematic categories: strength of character (15 items), head of family (14 items), caring for others (11 items), self-characteristics (11 items), protector and provider (10 items), responsibility ( 7 items), work (4 items), and service (4 items). These categories and items were then evaluated for the extent to which they were similar to or a repeat of other items and categories. This procedure resulted in 36 items in five categories that formed the MES subscales: Head of Family (8 items, e.g., lead family spiritually, solve problems that arise in the family, be responsible to family), Protector and Provider (6 items, e.g., protect children and family, provide for family, educate my children), Caring for Others (8 items, e.g., love family and friends, have love and affection, be responsible to society), Strength of Character (8 items, e.g., work hard, be tough, have discipline), and Self-characteristics (6 items, e.g., be independent as early as possible, know what is happening in the world, understand my own culture).

Participants were given the following instructions: "Think about your personal experience of what it means to be a man and rate how important the following are to you as a man by giving the number $1,2,3,4$, or 5 ." The response scale provided the following anchors: $1=$ Not important, $3=$ somewhat important, $5=$ very important . High scores indicate that a particular MES dimension is a salient aspect of a man's masculinity experiences. Cronbach's alphas for the MES were Head of Family, .88; Protector and Provider, .83; Caring for Others, .84; Strength of Character, .82; Self-characteristics, .81; MES total scale, .95. 
Wade, J. C., Suryani, L. K., \& Lesmana, C. B. J.

Religiosity Scale (RS) - The RS is a 6-item measure developed for the study to assess the extent to which an individual is involved with their religion. Items were developed based on the Religious Commitment Inventory-10 (RCI-10; Worthington, Jr. et al., 2003) because the RCI-10 is a measure that can be used to assess religious commitment in diverse religious groups. Example items include "I make an effort to deepen my understanding of the rules and teachings of my religion," "I frequently share my religious values with my friends," and "I go to religious services and ceremonies." Participants respond to items using a 5-point Likert scale where $1=$ Never and $5=$ Always. Cronbach's alpha was .74. Higher scores indicate greater involvement in Balinese Hindu religion and religious practices.

Contentment with Life Assessment Scale (CLAS) - The CLAS (Lavallee, Hatch, Michalos, \& McKinley, 2007) consists of 5 items that assess "feelings of contentment, sense of fulfillment, and discrepancies between one's actual life and one's wants or aspirations" (Lavallee et al., 2007, p. 205). Participants respond to items using a 7-point Likert scale where $1=$ strongly disagree and $7=$ strongly agree. However, we used a 6-point scale of agreement/disagreement. Because the Cronbach's alpha was low (.53), we eliminated three items resulting in a two-item scale with an alpha of .77. The two items were "I am very content with my life" and "I am living my life to the fullest.” Higher scores indicate greater life satisfaction.

Dyadic Satisfaction Scale (DSS) - Married men completed the 7-item DSS of the Dyadic Adjustment Scale (Hunsley, Pinsent, Lefebvre, James-Tanner, \& Vito, 1995) that assesses feelings of positive and global contentment with the marital relationship. Respondents are asked to indicate the approximate extent of agreement or disagreement "between you and your wife" for each item. Scale responses range from 1 (Never or Almost Never) to 5 (All the time). Example items include "How often do you discuss or have you considered divorce, separation, or terminating your marriage?" and "In general, how often do you think that things between you and your wife are going well?" Items reflecting negative satisfaction were reverse scored. Higher scores represent more positive feelings about the marital relationship. One item (i.e., "In general, how often do you think that things between you and your wife are going well?") was deleted to increase the reliability, resulting in a Cronbach's alpha of .74 .

Demographic Data - Participants were asked to provide their age, religion, marital status, years married, and occupation.

\subsection{Procedures}

The principal investigator and Balinese research assistant went to a park on three consecutive Sundays where local families customarily go on Sunday afternoons. The research assistant approached men who he identified as Balinese, introduced the principal investigator, explained the purpose of the study, and asked if they would like to participate. The participants completed the questionnaire while sitting in the park with the research assistant and investigator nearby to answer any questions. Participants were given 50,000 IDR (\$5.00 USD).

\subsection{Results}

Descriptive statistics - Means and standard deviations for the measures are provided in Table 2. The participants were very involved in their religion and religious practices. They reported having high satisfaction in their marital relationships and were very satisfied with their lives. All of the masculinity experiences were considered very important. T-tests indicated a significant difference between married and non-married participants for religiosity, $t(84)=2.92, p=.004$, whereby married men had a higher mean score. Therefore, marital status was controlled for when analyzing the relationships between religiosity and other variables.

We identified the masculinity experiences with highest percentages that were perceived as "very important." The items and the percentages of participants that responded with "very important" were as follows: Love the elderly (89.5), Appreciate parents and in-laws (89.5), Have discipline (88.2), Have responsibility (86.8), Have zest for life (86.8), Breadwinner (86.8), Provide for family (85.5), Have love and affection (85.5). 
Religiosity, masculinity, and marital and life satisfaction among Balinese Hindu men

Table 2

Descriptive Statistics

\begin{tabular}{llllc}
\hline & $N$ & Mean & $S D$ & Possible Range \\
\hline Life Satisfaction & 88 & 9.48 & 2.39 & $2-12$ \\
Marital Satisfaction & 71 & 23.60 & 3.75 & $6-30$ \\
Religiosity & 88 & 24.89 & 4.18 & $6-30$ \\
MES Head of Family & 76 & 37.61 & 3.90 & $8-40$ \\
MES Protector and Provider & 76 & 28.61 & 2.50 & $6-30$ \\
MES Caring for Others & 76 & 37.73 & 3.53 & $8-40$ \\
MES Strength of Character & 76 & 38.16 & 3.00 & $8-40$ \\
MES Self-characteristics & 76 & 26.57 & 3.70 & $6-30$ \\
Total MES & 76 & 169.39 & 14.00 & $36-180$ \\
\hline
\end{tabular}

Note. $\mathrm{SD}=$ standard deviation; MES = Masculinity Experiences Scale.

Correlational analyses - Correlations among the variables are provided in Table 3. Research question 2 asked, what are the relationships between masculinity, life satisfaction, and marital satisfaction? Life satisfaction significantly positively correlated with MES total score, $r(72)=.38, p=.001$, and with all MES subscales except for Strength of Character. Given the four significant subscale correlations with life satisfaction, we conducted multiple regression analysis to find out which of the masculinity experiences was the best predictor of life satisfaction. Results showed Caring for Others was the only subscale that was a significant predictor $(\beta=.50, t(71)=2.79, p=.007)$. With regard to marital satisfaction, only the Head of Family subscale significantly correlated with the DSS, $r(61)=.21, p=.049$.

Research question 3 asked, what is the relationship between religion/spirituality and men's marital and life satisfaction? The RS significantly positively correlated with life satisfaction, $r(83)=.40, p=.000$, but there was no significant correlation with marital satisfaction. Therefore, being involved with Balinese Hindu religion was positively associated with life satisfaction but had no relationship to marital satisfaction.

Research question 4 asked, what is the relationship between religion/spirituality and masculinity? The RS significantly positively correlated with total MES score, $r(68)=.53, p=.000$, and the five subscales. Thus, involvement in Balinese Hindu religion was positively associated with the importance of the masculinity experiences.

\section{Table 3}

Correlation Matrix

\begin{tabular}{|c|c|c|c|c|c|c|c|c|c|c|}
\hline & $\begin{array}{l}\text { Life } \\
\text { satisfaction }\end{array}$ & 2 & 3 & 4 & 5 & 6 & 7 & 8 & 9 & 10 \\
\hline 2. Marital satisfaction & -.04 & - & & & & & & & & \\
\hline 3. MES total & $.38 * *$ & .09 & - & & & & & & & \\
\hline 4. MES Head of Family & $.22 *$ & $.21 *$ & $.93^{* *}$ & - & & & & & & \\
\hline 5. MES Protector/Provider & $.21^{*}$ & .12 & $.90 * *$ & $.85^{* *}$ & - & & & & & \\
\hline 6. MES Caring for Others & $.42 * *$ & .18 & $.88^{* *}$ & $74 * *$ & $.72 * *$ & - & & & & \\
\hline 7. MES Character & .18 & .21 & $.90 * *$ & $75 * *$ & $.81^{*} *$ & $.75^{* *}$ & - & & & \\
\hline 8. MES Self-characteristics & $.28 *$ & .03 & $.84 * *$ & $.76^{* * *}$ & $.62 * *$ & $.69 * *$ & $.65^{* *} *$ & - & & \\
\hline 9. Religiosity ${ }^{\mathrm{a}}$ & $40 * *$ & -.07 & $53 * *$ & $.42 * *$ & $.44 * *$ & $50 * *$ & $.33 * *$ & $.44 * *$ & - & \\
\hline 10. Age & .13 & .10 & .12 & .10 & $.21^{*}$ & .16 & .00 & .04 & .05 & - \\
\hline 11. Marital status & .11 & - & .02 & .05 & .10 & -.06 & -.05 & -.07 & $.28 * *$ & $.48 * *$ \\
\hline
\end{tabular}

Regression analyses - Conceptually, we first considered whether religiosity was a mediator in the relationship between masculinity and life satisfaction. In such a model masculinity would "cause" one's religiosity. However, Balinese religion is a way of life and involves virtually every aspect of the society (Geertz $\&$ Geertz, 1975). As such, religion would be the basis for the importance of men's masculinity experiences, such that religiosity would cause one to view the masculinity experiences as important. Similarly, we considered 
whether masculinity was a mediator in the relationship between religiosity and life satisfaction. However, conceptually, masculinity would not be the causal link between religiosity and life satisfaction; that is, whether one viewed the masculinity experiences as important or not should not have an effect on the relationship between one's religiosity and life satisfaction. Lastly, we considered a conceptual model based on the confounding hypothesis. "The confounding hypothesis suggests that a third variable explains the relationship between an independent and dependent variable," but "unlike the mediational hypothesis, confounding does not necessarily imply a causal relationship among the variables" (MacKinnon, Krull, \& Lockwood, 2000, p. 2). As such, the model we tested was that more religious men are likely to view the masculinity experiences as important as well as be satisfied with their life. Therefore, masculinity and life satisfaction are related through a common confounder, religiosity (see Figure 1).

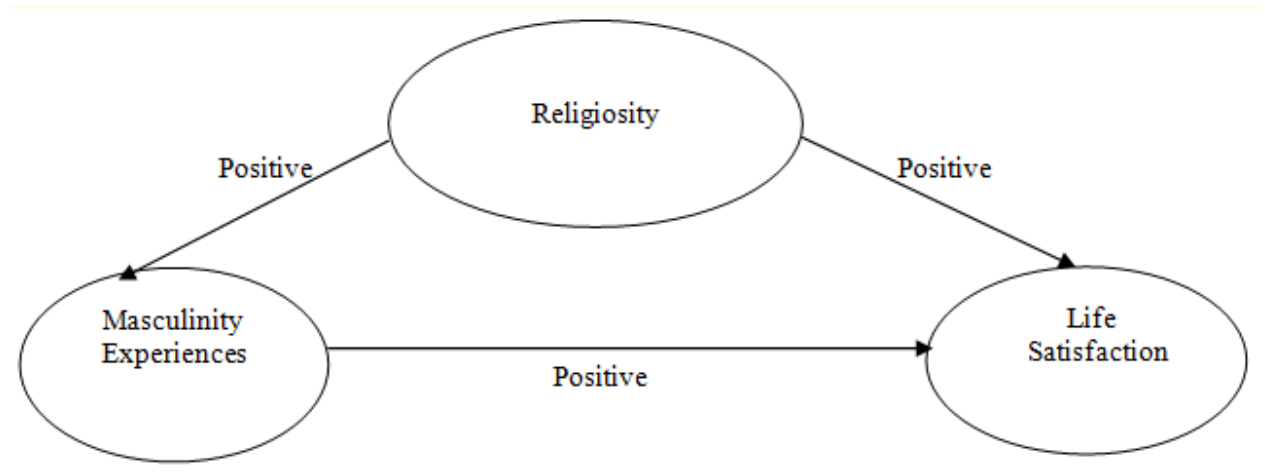

Figure 1. The confounding effect of religiosity on the positive relationship between masculinity experiences and life satisfaction

The test for a confounding effect is the same procedure as for a test of mediation. Therefore, we tested this hypothesis using three regression equations (Baron \& Kenny, 1986), controlling for marital status and using mean substitution for missing values (i.e., 5 values across 5 cases). First, religiosity was regressed on masculinity $(\beta=.50, t(76)=5.16, p=.000)$. Second, life satisfaction was regressed on masculinity $(\beta=.35, t(76)$ $=3.19, p=.002)$. Third, life satisfaction was regressed on both masculinity $(\beta=.18, t(76)=1.47, p=.147)$ and religiosity $(\beta=.34, t(76)=2.65, p=.010)$. In this regression equation that includes both masculinity and religiosity, the effect of masculinity on life satisfaction is reduced and is no longer significant. Thus, religiosity accounts for the relationship between importance of the masculinity experiences and life satisfaction.

According to Ludlow and Klein (2014), the third variable estimation procedure is the same for the second predictor whether it is a mediator or confounder. We conducted the test for the significance of the confounder effect using Preacher and Hayes's (2004) method of calculating standard errors and 95\% confidence intervals of the effect of masculinity on life satisfaction through religiosity. This method uses 5,000 bootstrapped samples to estimate the bias corrected and accelerated confidence intervals. The test of indirect effects showed the confounding effect $=.06, S E=.03,95 \% C I=.01$ to .12 . Because the confidence interval did not contain zero, we could conclude that there was a significant confounder effect of religiosity.

\section{Discussion}

The purpose of this study was to discover how masculinity and religiosity are related to marital and life satisfaction in Balinese Hindu men. The approach taken was one in which we wanted to discover how Balinese masculinity is configured and is associated with marital and life satisfaction. Additionally, Balinese spiritual values dictate the mode of living, and every aspect of Balinese life is steeped in religious belief (Covarrubias, 1937). Given the changes taking place in Bali with the dramatic rise in tourism as well as changes with respect to women's emancipation in all of Indonesia, it was important to consider how religious continuity may be related to men's marital and life satisfaction during these changes.

The group interviews and "As a man" responses provided the data that was analyzed to discover how Balinese 
men define masculinity: what it means to be a man and what experiences are associated with being a man. There was congruence between Balinese cultural values and the masculine ideal. One's role and responsibilities within the family and community are important. Men are concerned with the happiness of others and creating harmony in relationships. Additionally, being a man means you work hard to achieve, and value hard work and education. Human relationships are more important than money. Manhood means doing what other males do and/or with each other (e.g., playing and winning at sports) and is in contrast to what is afforded women in society (e.g., being able to express feelings of sadness, having "less" financially than the man).

Although manhood means valuing human relationships (harmony) over money, having money is an important part of being a man. For adult men, money is needed to fulfill one's familial role as breadwinner/provider. Money also has value for participation in religious ceremonies, of which there are many. Money has different significance for male youth. In Noszlopy's (2005) analysis of Balinese male youth culture, she noted that boys' concern with their attractiveness to girls hinges on their actual or potential material wealth. However, she also observed that boys had an "unambivalent commitment to local values of tradition" (p. 193) or customs, and this attachment to customs is essential to their sense of self and place.

Five areas were identified that describe Balinese masculinity. As head of family a man is responsible for his family. He is a role model to his wife and children, leads his family spiritually, solves problems that arise in the family, and avoids divorce. As the protector and provider of his family, he protects and provides for his family, educates his children, has the breadwinner role, and is a good father. Manhood involves caring for others, which means having love for one's family, friends, and the elderly; giving comfort to one's family; appreciating one's parents and in-laws; and being responsible to society. A man has strength of character: he is tough, works hard, has discipline, abides by the teachings of religion, makes wise decisions, and faces challenges. Lastly, certain aspects of masculinity are considered characteristics of the self, such as being independent as early as possible, knowing what is happening in the world, understanding one's culture, having a good life, and having insight into the future.

Of the masculinity experiences having the highest percentages for being "very important," three were related to caring for others of which two had the highest percentages. These findings lend support to the qualitative data that indicates Balinese manhood places importance on human relationships and the happiness of others, especially within the family and community. In a study of Javanese Muslim men, the top ten masculinity attributes were all related to head of family responsibilities, although having constructive relationships with others was also identified as a masculinity attribute (Wade \& Wiloso, 2016) and within Javanese culture harmony is the most important value in human relationships (Albert, Trommsdorff, Mayer, \& Schwarz, 2005; Megawangi, Zeitlin, \& Colletta, 1995). Additionally, the finding for Balinese men is inconsistent with a study of 10,934 men across five Asian countries (China, Korea, Japan, Malaysia, Taiwan) in which having a good job, being seen as a man of honor, and being in control of your own life were found to be the top three most important masculinity attributes (Ng, Tan, \& Low, 2008). However, the study did not include Indonesian men, and of the 13 masculinity attributes listed, none reflected the attribute of caring for others.

The other top very important experiences were related to family roles and strength of character. The importance of family roles is consistent with the Indonesian Marriage Law and what gender scholars have observed with regard to hegemonic Indonesian masculinity (Nilan, 2009; Oetomo, 2000). Men are the breadwinners and head of the family. Additionally, results from a study of 19 non-Western countries indicated that in all countries the breadwinner provider role was "the first and most likely mentioned definition of a man's role in the family and of a good husband" (World Development Report, 2012, p. 194).

The characteristics of Balinese masculinity coincide with the characteristics of positive masculinity in American culture as described by Kiselica, Benton-Wright, and Englar-Carlson (2015). In particular, the authors noted the characteristics of male ways of caring (caring for and protecting loved ones and friends), generative fatherhood (caring for and meeting children's needs), worker-provider tradition (work to provide for loved ones), and male forms of service (providing service to the community and society) that are most consistent with the 
Wade, J. C., Suryani, L. K., \& Lesmana, C. B. J.

masculinity of Balinese men. In this regard, our research showed Balinese masculinity was positively associated with life satisfaction; however, caring for others was the only significant predictor.

Given harmonious relationships is a central cultural value, the importance of caring for others is likewise a central characteristic of manhood. Two studies have reported comparable findings. A communal orientation to relationships is one in which the individual is inclined to care for and give care to both close and distant others (Le, Impett, Kogan, Webster, \& Cheng, 2012). In a sample of college students in the US, Le et al. (2012) found a communal orientation was associated with experiencing positive emotions on a daily basis. More specific to the study of men and positive masculinity, Estrada and Arciniega (2015) examined the relationships between caballerismo, religiosity, and life satisfaction in a sample of primarily Mexican/Mexican American men. Caballerismo "comprises attributes related to family centeredness, social responsibility, and emotional connectedness" (p. 192). Their results showed that religious involvement moderated the positive relationship between caballerismo and satisfaction with life, such that only at high levels of religious involvement was caballerismo a predictor of satisfaction with life. The authors reasoned that religious values may be supportive of the values of positive masculinity (i.e., caballerismo). Similarly, in our study it may be the congruence between personal and cultural values that contributes to life satisfaction among Balinese Hindu men.

An excerpt from the key informant interview with the Balinese man sheds light on why caring for others would be important to life satisfaction.

Interviewer: "Balinese men are different from American men. I asked myself why?"

Key Informant: "You are taught to be a very strong one. I understand that. Because maybe the system of social life is different. Like in Europe also. The boy is taught to be the strong one. To face his own problem. In Bali it is like that but we also teach them how to have good contact with other Balinese people. Good relationship especially within the same community. Because if we have bad conduct in the social community we can be exiled. We cannot be accepted again to be a member of the village community, and it is very hard for us. Because we will have no symmetry. And then when someone dies of our family we are not allowed to cremate him or her in the cemetery."

Here, the key informant is describing how boys are socialized to have good relationships with others and the potential consequences of being exiled from the community.

With regard to marital satisfaction, men who regard being the head of the family as an important aspect of Balinese manhood were also more likely to be satisfied with their marriage. No research has specifically examined the head of family role and men's marital satisfaction, possibly "because the role is considered to be a dated construct and a traditionally outmoded male role" (Siraj, 2010, p. 197). However, in a study of 25,847 married or cohabiting adults from 34 developed countries, both men and women in traditional relationships reported slightly higher family satisfaction on average, compared to respondents in non-traditional relationships (Forste \& Fox, 2012). Traditional relationship was conceptualized as man-breadwinner, woman-homemaker. In addition to traditional marital relationships, the head of the family role as important to manhood and men's marital satisfaction may be particular to religious cultural contexts: for example, Muslims that base marital roles on the Qur'an (Siraj, 2010), evangelical Christians that base marital roles on the Bible (Coltrane, 2001), and Mormon theology in which men are designated to be the spiritual leaders and heads of Mormon households (Heaton, 1988).

Involvement in Balinese Hindu religion was positively associated with the importance of the masculinity experiences and life satisfaction. The relationship found between religiosity and life satisfaction is supported by a study in which 79 nations indicated "religiosity makes people happier in religious nations" (Okulicz-Kozaryn, 2009 , p. 15). However, the finding that religiosity was not associated with marital satisfaction is contrary to many studies that have examined this relationship (see Orathinkal \& Vansteenwegen, 2006). 
Given the significant positive associations among religiosity, masculinity, and life satisfaction, we hypothesized that religiosity would explain why the masculinity experiences are important and have a relationship to life satisfaction. The results supported the hypothesis. How Balinese men view manhood is intimately tied to their religion, which is the foundation of their culture and its values. Congruence between religiosity and Balinese masculinity within Balinese society contributes to men's satisfaction with life.

There are several limitations to this study that deserve mentioning. The sample size for the descriptive study was small and took place in the capital city of Denpasar, which makes generalizability of the results limited. Future research should consider using a larger sample size including participants from other geographic locations. Additionally, although the individual responses in the group interview were translated, there is always something that is missed in the translation. Similarly, the translation for some of the items on the questionnaire may have not been clear to participants, which could affect the reliability of the measures. Relatedly, response styles or bias in responding to Likert-type items can be affected by culture. It has been argued that in collectivist cultures, in which harmony and conformity are valued, response styles will tend to be either in the middle to positive range (Harzing, 2006). We also did not include a measure of social desirability to control for socially desirable responding. Lastly, most of the measures used in this study were developed for the purposes of this study. Thus, there is little support for the validity of the new measures other than reliability.

The measure of masculinity experiences assesses the importance of certain characteristics associated with manhood for oneself, and they are also experiences that could be considered "positive." It is possible that there are other masculinity experiences that we did not identify or that are contrary to what we identified. Future research could investigate masculinity from a normative perspective, conformity to masculine norms, and/or those aspects of masculinity that are considered negative in order to uncover problematic aspects of masculinity. Additionally, research is needed using the MES to determine if different samples of Balinese men, as well as women, agree that these experiences are important and how they relate to different areas of men's and women's' lives.

In conclusion, the findings shed light on Balinese men's conceptions of masculinity and how they relate to men's' religiosity, marital satisfaction, and life satisfaction. Caring for others as a masculinity attribute was unique in predicting life satisfaction, whereas the importance of head of the family was uniquely associated with marital satisfaction. Additionally, religiosity explained the positive relationship between the masculinity attributes and life satisfaction. These significant associations should be considered within the context of Indonesia and Balinese culture; caring for others corresponds with the Balinese cultural value of harmony in relationships, and men as head of the family corresponds with Indonesian marital law and Balinese patriarchal society. The implications of the research for practice, learners, and teachers is in the knowledge gained about the intersectionality of religion and masculinity as they relate to men's life satisfaction. It would be important for clinicians working with Balinese Hindu men to assess their masculinity ideology and the extent to which they are involved with their religion. Their beliefs about being a Balinese Hindu man may be related to how satisfied they are with their life, and problems with low mood or self-esteem. If there is marital dissatisfaction, it would be important to evaluate his feelings about his role in the family; in particular, as the head of family. Within the field of psychology, men and masculinity is an area of needed attention in order to understand men's issues. Additionally, given the changing gender roles in Indonesia and the effects of increased tourism in Bali, our findings suggest that religiosity may serve as a protective factor that helps Balinese men deal with the changes occurring in Bali, and being head of the family may contribute to their marital satisfaction as Indonesia moves toward gender equality and the empowerment of women.

Acknowledgements - This research was supported by the Fulbright Senior Research Scholar Award. We would like to thank Gede Hening Pratama for his assistance on this research project. This research was approved by the Fordham University Institutional Review Board (IRB) and the State Ministry of Research and Technology, Jakarta, Indonesia. 


\section{References}

Adamson, C. (2007). Gendered anxieties: Islam, women's rights, and moral hierarchy in Java. Anthropological Quarterly, 80(1), 5-37. https://doi.org/10.1353/anq.2007.0000

Albert, I., Trommsdorff, G., Mayer, B., \& Schwarz, B. (2005). Value of children in urban and rural Indonesia: Socio-demographic indicators, cultural aspects, and empirical findings. In G. Trommsdorff \& B. Nauck (Eds.), The value of children in cross-cultural perspective. Case studies from eight societies (pp. 171-207). Lengerich, Germany: Pabst Science.

Baron, R. M., \& Kenny, D. A. (1986). The moderator-mediator variable distinction in social psychological research: Conceptual, strategic, and statistical considerations. Journal of Personality and Social Psychology, 51, 1173-1182. https://doi.org/10.1037/0022-3514.51.6.1173

Cammack, M., Bedner, A., \& van Huis, S. (2015, May). Democracy, human rights, and Islamic family law in Post-Soeharto Indonesia. New Middle Eastern Studies, 5. Retrieved from http://www.brismes.ac.uk/nmes/archives/1413

Christensen, P. (2013, January 1). Sister in danger: Youth against sexual violence. Bali Advertiser. Retrieved from https://baliadvertiser.biz

Clark, M. A. (2010). Maskulinitas: Culture, gender and politics in Indonesia. Victoria, Australia: Monash University Press.

Coltrane, S. (2001). Marketing the marriage "solution": Misplaced simplicity in the politics of fatherhood. Sociological Perspectives, 44(4), 387-418.

Covarrubias, M. (1937). Island of Bali. New York: Alfred A. Knopf, Inc.

Estrada, F., \& Arciniega, G. M. (2015). Positive masculinity among Latino men and the direct and indirect effects on well-being. Journal of Multicultural Counseling and Development, 43, 191-205. https://doi.org/10.1002/jmcd.12014

Fontana, A., \& Frey, J. H. (1994). Interviewing: The art of science. In N. K. Denzin \& Y. S. Lincoln (Eds.), Handbook of qualitative research (pp. 361-376). Thousand Oaks, CA: Sage Publications.

Forste, R., \& Fox, K. (2012). Household labor, gender roles, and family satisfaction: A cross-national comparison. Journal of Comparative Family Studies, 43(5), 613-631.

Geertz, H., \& Geertz, C. (1975). Kinship in Bali. Chicago: The University of Chicago Press.

Harzing, A. (2006). Response styles in cross-national survey research: A 26-country study. International Journal of Cross Cultural Management, 6, 243-266. https://doi.org/10.1177/1470595806066332

Heaton, T. B. (1988). Four C's of the Mormon family: Chastity, conjugality, children, and chauvinism. In D. L. Thomas (ed.), The religion and family connection: Social science perspectives (pp. 107-124). Provo, UT: Religious Studies Center, Brigham Young University. Retrieved from https://rsc.byu.edu/archived/religion-and-family-connection-social-science-perspectives/chapter-6-fourc-s-mormon-family

Hunsley, J., Pinsent, C., Lefebvre, M., James-Tanner, S., \& Vito, D. (1995). Assessment of couples, marriages, and families. Construct validity of the short forms of the Dyadic Adjustment Scale. Family Relations, 44, 231-237. https://doi.org/10.2307/585520

IANS. (February 05, 2009). Divorce rates jump in Indonesia after reforms. Thaindian News. Retrieved from http://www.thaindian.com/newsportal/uncategorized/divorce-rates-jump-in-indonesia-after-reforms_100 151476.html

Kiselica, M. S., Benton-Wright, S., \& Englar-Carlson, M. (2015). Accentuating positive masculinity: A new foundation for the psychology of boys, men, and masculinity (pp. 123-143). In Y. J. Wong \& S. R. Wester (Eds.), APA handbook of men and masculinities. Washington DC: American Psychological Association.

Kurniawan, L., \& Chandra, G. N. (2016, August). Domestic violence and mental health: Study of Bali integrated service center for children and women empowerment. Poster presented at the 21 st ISPCAN International Congress on Child Abuse and Neglect, Calgary, Alberta, CA. Retrieved from 
Religiosity, masculinity, and marital and life satisfaction among Balinese Hindu men

http://programme.exordo.com/ispcan2016congress/delegates/presentation/388/

Lavallee, L. F., Hatch, P. M., Michalos, A. C., \& McKinley, T. (2007). Development of the Contentment with Life Assessment Scale (CLAS): Using daily life experiences to verify levels of self-reported life satisfaction. Social Indicators Research, 83, 201-244. https://doi.org/10.1007/s11205-006-9054-6

Le, B. M., Impett, E. A., Kogan, A., Webster, G. D., \& Cheng, C. (2012). The personal and interpersonal rewards of communal orientation. Journal of Social and Personal Relationships, 30(6), 694-710. https://doi.org/10.1177/0265407512466227

Lewis, J., \& Lewis, B. (2009). Bali's silent crisis: Desire, tragedy and transition. Lanham, MD: Lexington Books.

Ludlow, L., \& Klein, K. (2014). Suppressor variables: The difference between "Is" versus "Acting As." Journal of Statistics Education, 22(2), 1-27. https://doi.org/10.1080/10691898.2014.11889703

Lukito, R. (2012). Legal pluralism in Indonesia: Bridging the unbridgeable. New York: Routledge.

MacKinnon, D. P., Krull, J. L., \& Lockwood, X. M. (2000). Equivalence of the mediation, confounding and suppression effect. Prevention Science, 1(4), 173-181. https://doi.org/10.1023/A:1026595011371

Megawangi, R., Zeitlin, M. F., \& Colletta, N. D. (1995). The Javanese family. In M. F. Zeitlin, R. Megawangi, E. M. Kramer, N. D. Colletta, E. D. Babatunde, \& D. Garman (Eds.), Strengthening the family: Implications for international development (pp. 95-141). Tokyo: United Nations University.

Newell, S., \& Stubbs, B. (1999). Targeting society and environment. Glebe, Australia: Blake Education.

Ng, C. J., Tan, H. M., \& Low, W. Y. (2008). What do Asian men consider as important masculinity attributes? Findings from the Asian Men's Attitudes to Life Events and Sexuality (MALES) Study. Journal of Men's Health, 5(4), 350-355. https://doi.org/10.1016/j.jomh.2008.10.005

Nilan, P. (2009). Contemporary masculinities and young men in Indonesia. Indonesia and the Malay World, 37(109), 327-344. https://doi.org/10.1080/13639810903269318

Noszlopy, L. (2005). Bazar, big kites and other boys' things: Distinctions of gender and tradition in Balinese youth culture. The Australian Journal of Anthropology, 16(2), 179-197. https://doi.org/10.1111/j.1835-9310.2005.tb00033.x

Oetomo, D. (2000). Masculinity in Indonesia: Genders, sexualities and identities in a changing society. In R. Parker, R. M. Barbosa, \& P. Aggleton (Eds.), Framing the sexual subject: The politics of gender, sexuality and power (pp. 46-59). Berkeley, CA: University of California Press.

Okulicz-Kozaryn, A. (2009). Religiosity and life satisfaction: A multilevel investigation across nations. Retrieved from http://www.asrec.org/wp-content/uploads/2015/10/Okulicz-Kozaryn-LIfe-Satisfaction-ASREC09.pdf

Orathinkal, J., \& Vansteenwegen, A. (2006). Religiosity and marital satisfaction. Contemporary Family Therapy, 28, 497-504. https://doi.org/10.1007/s10591-006-9020-0

Parker, L. (2003). Balinese. In C. R. Ember \& M. Ember (Eds.), Encyclopedia of sex and gender: Men and women in the world's cultures (Vol. 1, pp. 303-313). New York: Springer. https://doi.org/10.1007/0-387-29907-6_30

Pew Research Center. (2015). The future of world religions: Population growth projections, 2010-2050. Why Muslims are rising fastest and the unaffiliated are shrinking as a share of the world's population. Retrieved from http://www.pewforum.org/2015/04/02/muslims/

Poerwandari, E. K., Sadli, S., \& Ihromi, T. O. (2005). Introduction. In E. K. Poerwandari (Ed.), Indonesian women in a changing society (pp. 15-40). Seoul, Korea: Ewha Woman's University Press.

Preacher, K. J., \& Hayes, A. F. (2004). SPSS and SAS procedures for estimating indirect effects in simple mediation models. Behavior Research Methods, Instruments, \& Computers, 36, 717-731. https://doi.org/10.3758/BF03206553

Radzmi, D. (2014, February 26). Three things that Malaysia can learn from Bali's success in tourism. Business Insider Malaysia. Retrieved from http://www.businessinsider.my/3-things-that-malaysia-can-learn-from-balis-success-in-tourism/\#8LjPsJ 74H3FJhRkk.97

Salim, A., \& Azra, A. (Eds.) (2003). Shari'a and politics in modern Indonesia. Singapore: Institute of Southeast 
Wade, J. C., Suryani, L. K., \& Lesmana, C. B. J.

Asian Studies. https://doi.org/10.1355/9789812305206

Siraj, A. (2010). "Because I'm the man! I'm the head": British married Muslims and the patriarchal family structure. Contemporary Islam, 4, 195-214. https://doi.org/10.1007/s11562-010-0120-0

Suryani, L. K. (2004). Balinese women in a changing society. Journal of the American Academy of Psychoanalysis, 32, 213-230. https://doi.org/10.1521/jaap.32.1.213.28335

Wade, J. C. (1998). Male reference group identity dependence: A theory of male identity. The Counseling Psychologist, 26, 349-383. https://doi.org/10.1177/0011000098263001

Wade, J. C., \& Wiloso, P. G. (2016). Religiosity, masculinity, and marital satisfaction among Javanese Muslim men. International Journal of Research Studies in Psychology, 5(3), 37-52. https://doi.org/10.5861/ijrsp.2016.1468

Wayan. (2015, October 30). Tri Hita Karana: Three harmonious relationships. World Hindu Parisad. Retrieved from http://www.worldhinduparisad.org/eng/?p=1546

Winarti, A. (2013, January 19). No heaven for women, children in Bali. The Jakarta Post. Retrieved from http://www.thejakartapost.com

Wong, Y. J., Shea, M., LaFollette, J. R., Hickman, S. J., Cruz, N., \& Boghokian, T. (2011). The Inventory of Subjective Masculinity Experiences: Development and psychometric properties. Journal of Men's Studies, 19, 236-255. https://doi.org/10.3149/jms.1903.236

World Development Report. (2012). The decline of the breadwinner: Men in the 21st century. Defining Gender in the 21st Century: A Multi-Country Assessment. Retrieved from http://siteresources.worldbank.org/INTWDR2012/Resources/7778105-1299699968583/7786210-13160 90663409/Spread-2.pdf

World Hindu Parisad. (n.d.). About Bali. Retrieved from http://www.worldhinduparisad.org/eng/?page_id=1038

Worthington, E. L., Jr., Wade, N. G., Hight, T. L., Ripley, J. S., McCullough, M. E., Berry, J. W., \& O’Connor, L. O. (2003). The Religious Commitment Inventory-10: Development, refinement, and validation of a brief scale for research and counseling. Journal of Counseling Psychology, 50(1), 84-96.

https://doi.org/10.1037/0022-0167.50.1.84 